\title{
Author Index Volume 10 (1997)
}

The issue number is given in front of the page numbers.

Guidelines for red blood cell and plasma transfusion for adults and children

International seminar on Drugs and Pregnancy held in Ebeltoft, Denmark, 1-2 May 1996

(4) 255-271

Profile: EURO DURG: the European Drug Utilization Research Group

(3) $\quad 187$

(2) $\quad 131$

Abraham, J.W., Secrecy and drug regulation in Europe: who is being protected?

(3) $143-146$

Achiron, A., see Barak, Y.

(3) $211-215$

Achiron, A., see Kimhi, R.

Andersen, B.S., T. Mätzsch, D. Bergqvist, B.I. Eriksson and C. Törholm, Location of postoperative deep vein thrombosis in relation to age and survival

(3) $207-210$

Aviv, A., see Levy, D.

(4) $229-234$

(1) $27-30$

Bar, J., D. Rabinerson, A. Padoa, Z. Nitzan, A. Neri, B. Fisch and M. Hod, The effect of low-dose aspirin treatment on biochemical markers in pregnant hypertensive patients

Bar, J., M. Hod and P. Merlob, Angiotensin converting enzyme inhibitors use in the first trimester of pregnancy

Barak, Y., A. Achiron, A. Elizur, H. Szor and B. Shohat, Screening for Human T-cell Lymphotrophic Virus type-I (HTLV-I) infection in high risk schizophrenic patients

Barak, Y., see Kimhi, R.

Barak, Y., see Levy, D.

Bergqvist, D., see Andersen, B.S.

(4) 249-254

(1) $23-26$

(3) $211-215$

(3) $207-210$

(1) $27-30$

(4) $229-234$

Dagan, D., see Merlob, P.

(4) $235-242$

Dalla-Vorgia, P., see Lascaratos, J.

(1) $51-56$

Elizur, A., see Barak, Y.

(3) $211-215$

Elizur, A., see Kimhi, R.

(3) $207-210$

Elizur, A., see Levy, D.

Eriksson, B.I., see Andersen, B.S.

(1) $27-30$

(4) 229-234

Fielder, J.H., see Mol, B.A.J.M de

(4) $243-247$

Fisch, B., see Bar, J.

(4) 249-254

Grech, V., see Savona-Ventura, C.

(1) $31-39$

Hod, M., see Bar, J.

(1) $23-26$

Hod, M., see Bar, J.

(4) 249-254

Irgens, L., see Lie, R.T.

Jong-van den Berg, L. de, see Sørensen, H.T.

(3) 193-195 
Kimhi, R., Y. Barak, A. Achiron and A. Elizur, Hepatitis among psychiatric inpatients: a high-risk group?

Kimhi, R., see Levy, D.

(3) $207-210$

(1) $27-30$

Lascaratos, J. and P. Dalla-Vorgia, The penalty of mutilation for crimes in the Byzantine era (324-1453 A.D.)

Levi, N., Cervical hip fractures treated with internal fixation: are operative delay and old age risk factors?

Levi, N., Deep infection following total ankle arthroplasty

Levi, N. and T. Nordentoft, Intertrochanteric femoral fractures: a new method for predicting the risk of failure

Levy, D., R. Kimhi, Y. Barak, A. Aviv, O. Pinhas-Hamiel and A. Elizur, Acute neuroleptic induced leukopenia in Ethiopian jews with benign familial leukopenia

Lie, R.T. and L. Irgens, The Norwegian national birth cohort

(1) $51-56$

(3) $217-222$

(1) $47-49$

(1) $41-46$

(1) $27-30$

(3) $\quad 191$

Mätzsch, T., see Andersen, B.S.

Medawar, C., The Antidepressant Web

Merlob, P., D. Dagan, B. Mogilner, B. Mulhbauer and L. Sirota, Twenty-one years of monitoring congenital malformations (1974-1994): The Israel Birth Defects Monitoring System, affiliated with the International Clearinghouse

Merlob, P., see Bar, J.

Mintzes, B., Conference report. The menopausal transition: a different view

Mogilner, B., see Merlob, P.

Mol, B.A.J.M de and J.H. Fielder, Systemic accident analysis of deaths due to failed BjörkShiley heart valves

Mortensen, E.L., The Copenhagen Perinatal Cohort and the Prenatal Development Project

Mulhbauer, B., see Merlob, P.

(4) $229-234$

(2) $75-126$

(4) $235-242$

(1) $23-26$

(2) $127-130$

(4) $235-242$

(4) $243-247$

(3) $199-202$

(4) $235-242$

Neri, A., see Bar, J.

Nielsen, G.L., see Zhou, W.

Nielsen, G.L., H.T. Sørensen, W. Zhou, F.H. Steffensen and J. Olsen, The Pharmacoepidemiologic Prescription Database of North Jutland - a valid tool in pharmacoepidemiological research

Nitzan, Z., see Bar, J.

Nordentoft, T., see Levi, N.

(4) $249-254$

(3) $189-190$

Olsen, J. and H.T. Sørensen, The Danish national birth cohort - a valuable tool for pharmacoepidemiology in pregnancy

Olsen, J., see Nielsen, G.L.

Olsen, J., see Zhou, W.

(3) 203-205

(4) $249-254$

(1) $41-46$

(3) $197-198$

(3) 203-205

(3) $189-190$

Padoa, A., see Bar, J.

Persson, L. and L. Westerhäll, Pharmaceutical Injury Insurance in the Nordic countries - an alternative to the traditional law of tort

Pinhas-Hamiel, O., see Levy, D.

(4) $249-254$

(3) $147-185$

(1) $27-30$

Rabinerson, D., see Bar, J.

(4) $249-254$

Savona-Ventura, C. and V. Grech, Congenital malformations in a central Mediterranean island Shohat, B., see Barak, Y.

Sirota, L., see Merlob, P.

Sørensen, H.T., Regional administrative health registries as a resource in clinical epidemiology

(1) $31-39$

(3) $211-215$

(4) $235-242$

(1) $1-22$ 
Sørensen, H.T. and L. de Jong-van den Berg, Pharmacoepidemiological studies in pregnancy: the need for international collaboration

(3) $193-195$

Sørensen, H.T., see Nielsen, G.L.

Sørensen, H.T., see Olsen, J.

Sørensen, H.T., see Zhou, W.

Steffensen, F.H., see Nielsen, G.L.

Steffensen, F.H., see Zhou, W.

Szor, H., see Barak, Y.

(3) $203-205$

(3) $197-198$

(3) $189-190$

(3) $203-205$

(3) $189-190$

(3) $211-215$

Törholm, C., see Andersen, B.S.

(4) $229-234$

Van Hall, E.V., Guest editorial. The menopause: physiology or pathology?

(2) $71-74$

Westerhäll, L., see Persson, L.

(3) $147-185$

Zhou, W., F.H. Steffensen, H.T. Sørensen, G.L. Nielsen and J. Olsen, Drug use in pregnancy in the county of North Jutland - preliminary analyses based on 6142 pregnancies

(3) $189-190$

Zhou, W., see Nielsen, G.L.

(3) 203-205 